\title{
Effects of UV radiation on DNA photodamage and production in bacterioplankton in the coastal Caribbean Sea
}

\author{
Petra M. Visser ${ }^{1,2, *}$, Eveline Snelder ${ }^{1}$, Arjen J. Kop ${ }^{1}$, Peter Boelen ${ }^{1,3}$, \\ Anita G. J. Buma ${ }^{3}$, Fleur C. van Duyl ${ }^{1}$ \\ ${ }^{1}$ Netherlands Institute for Sea Research (NIOZ), Department of Biological Oceanography, PO Box 59, 1790 AB Den Burg, \\ Texel, The Netherlands \\ ${ }^{2}$ CARMABI Ecological Institute, PO Box 2090, Curaçao, Netherlands Antilles, \\ ${ }^{3}$ Department of Marine Biology, University of Groningen, PO Box 14, 9750 AA Haren, The Netherlands
}

\begin{abstract}
This study focuses on the effects of ultraviolet radiation (UVR) on bacterioplankton. The effect of different parts of the sunlight spectrum on the leucine and thymidine incorporation and on the induction of DNA damage in natural bacterial populations in the coastal Caribbean Sea off Curaçao were investigated. DNA photodamage in microorganisms and biodosimeters was quantified by the number of cyclobutane dimers (thymine dimers). Increasing DNA damage during the day was found when incubated in full surface solar radiation. When UVBR was excluded no DNA damage was observed, indicating that thymine dimers were only formed by UVB radiation. The amount of thymine dimers in the $>0.8 \mu \mathrm{m}$ fraction was only one-third of the amount of induced thymine dimers in the $<0.8 \mu \mathrm{m}$ fraction, suggesting that phytoplankton is less sensitive to UV-induced DNA damage than bacterioplankton. Protein and DNA synthesis was inhibited to about $30 \%$ of the dark control during the day when exposed to surface solar radiation. In both protein and DNA synthesis a trend was found, with the highest inhibition under full solar radiation, lower inhibition when UVBR was shielded off and the lowest inhibition when UVAR $(<375 \mathrm{~nm}$ ) was also shielded off. The intracellular carbohydrate content of the phytoplankton incubated under full solar radiation was not significantly higher than the dark incubation, while the contents after incubation without UVBR were significantly higher. The carbohydrate content in the samples incubated without UVBR and UVAR $(<375 \mathrm{~nm})$ was a little higher than with only UVBR shielded off. In summary, the results show that in the coastal Caribbean Sea UVBR is responsible for DNA damage in bacterio- and phytoplankton, while protein and DNA synthesis in bacterioplankton was inhibited by UVBR, UVAR and PAR and carbohydrate synthesis in phytoplankton by both UVBR and UVAR.
\end{abstract}

KEY WORDS: UV radiation - Bacterioplankton - DNA damage - Bacterial production · Phytoplankton . Carbohydrates

\section{INTRODUCTION}

Ultraviolet radiation (UVR) penetrating the water column is one of the physical variables influencing marine ecosystems in the euphotic zone (e.g. planktonic life and coral reefs). Due to the depletion of the ozone layer, UVBR research has become an important research topic. Research on the effects of UVR has con-

\footnotetext{
- Present address: ARISE/Microbiology, University of Amsterdam, Nieuwe Achtergracht 127, 1018 WS Amsterdam, The Netherlands.E-mail: petra.visser@chem.uva.nl
}

centrated mainly on the polar regions because the relative amount of UVBR ( 280 to $315 \mathrm{~nm}$ ) is mostly increasing in these areas due to the stratospheric ozone depletion (Crutzen 1992, Madronich 1993, 1994). However, the intensities of UVBR (280 to $315 \mathrm{~nm}$ ) and UVAR ( 315 to $400 \mathrm{~nm}$ ) reaching the earth's surface in tropical regions are naturally very high compared to other parts of the world due to the relatively thin ozone layer near the equator and the low zenith angle of the sun (Baker et al. 1980, Madronich 1993). UVBR has a much lower intensity than UVAR and PAR, but is a highly reactive component of sunlight. In the tropics, 
no significant trends in changes in ozone have been seen (Madronich 1993), but the UVB radiation is much higher than in Antarctica, even under ozone-hole conditions (Holm-Hansen et al. 1993).

Despite high natural UVR levels, very little is known about UVR as a natural stress factor in tropical organisms. Since marine ecosystems in tropical regions are often oligotrophic, UVR penetrates deeply into the water column. Coral reefs are situated at those latitudes receiving high UVR and this may affect the energy flows in coral reefs. In view of changes in the incoming UVR, either by increases in the incident radiation by depletion of the ozone layer or by changes in penetration, for instance as a result of changes in dissolved organic matter in polluted areas, the understanding of the role that UVR plays in the ecosystem will facilitate predictions of changes in the functioning of organisms.

UVR is known to cause DNA damage in various organisms. Different kinds of photoproducts are known, with cyclobutane pyrimidine dimers, the pyrimidine (6-4) pyrimidone and the Dewar pyrimidone as the most predominant ones (Mitchell \& Karentz 1993). From the cyclobutane pyrimidine dimers, thymine dimers occur with the highest frequency in nature (Mitchell \& Karentz 1993). Thymine dimers have been observed in aquatic organisms such as cultures of diatoms (Karentz et al. 1991, Buma et al. 1995), in different fractions $(<0.8$ and $<10 \mu \mathrm{m}>0.8 \mu \mathrm{m})$ of seawater samples (Jeffrey et al. 1996a,b) and in bacteria associated with the mucus layers of corals (Lyons et al. 1998). This DNA damage can have many consequences, the most important being that it inhibits the functioning of polymerase and thereby affects the growth rate.

Much research has focused on phytoplankton, and it has been found that UVR can decrease the growth rate by reduced photosynthesis, DNA damage or other damaged parts of the cells (e.g. Holm-Hansen et al. 1993, Vincent \& Roy 1993, Smith \& Cullen 1995). Little attention has been drawn to the effects of UVR on bacterioplankton, although it is now understood that heterotrophic bacteria are a large and productive component of the planktonic microbial food web in a variety of marine systems (Ducklow 1990).

Inhibition of incorporation of leucine (estimate of protein synthesis) and thymidine (estimate of DNA synthesis) in bacterioplankton by UVR has been shown by Aas et al. (1996) and Herndl et al. (1993, 1997). UVR can also affect bacterioplankton indirectly. Firstly, photolysis of dissolved organic carbon can increase the available substances for uptake by bacteria, which can stimulate bacterial productivity (Lindell et al. 1995, Herndl et al. 1997). Secondly, bacterivorous grazers can be reduced in their motility and grazing activity by
UVR (Sommaruga et al. 1996). All different effects of UVR have consequences for the functioning of the microbial food web.

This study focused on the effects of UVR on bacterioplankton. The aim of the study was to gain more insight into the impact of sunlight on bacterial production and energy flows in the microbial food web in tropical waters. The effect of different parts of the sunlight spectrum on leucine and thymidine incorporation and on induction of DNA damage in natural populations in the Caribbean Sea off Curaçao were investigated. Measurements were performed after short-term incubations $(3 \mathrm{~h}$ ) and followed on a diurnal time scale. DNA damage was determined in fractionated samples in order to investigate possible differences in sensitivity to UVR between phytoplankton and bacterioplankton. Biodosimeters were used to estimate the biologically effective doses of UVBR. Quantification of cyclobutane pyrimidine dimers in pure DNA was used as a reliable measure for the biologically effective UVB dose by Jeffrey et al. (1996ab), Regan et al. (1992) and Boelen et al. (1999). Boelen et al. (1999) showed that the induction of DNA damage as measured with these biodosimeters correlated well with biologically effective irradiance calculated from spectroradiometer measurements, using the DNA action spectrum of Setlow. The diurnal changes of the intracellular carbohydrate content in phytoplankton, as an estimate of primary production, were also followed in bags incubated under different parts of the sunlight spectrum. Furthermore, the effect of the presence of phytoplankton on the response of bacteria to UV was investigated.

\section{MATERIAL AND METHODS}

Incubations to measure DNA damage and protein synthesis. Experiments were performed at Curaçao $(60 \mathrm{~km} \times 11 \mathrm{~km})$, one of the Netherlands Antilles in the southern Caribbean. Surface samples were taken on the morning of the experiments between 08:15 and $08: 45 \mathrm{~h}$ at a spot (of $>100 \mathrm{~m}$ depth) about $1 \mathrm{~km}$ south of the Carmabi Institute $\left(12^{\circ} 07^{\prime} \mathrm{N}, 69^{\circ} 57^{\prime} \mathrm{W}\right.$, south coast of Curaçao, $5 \mathrm{~km}$ north-east of the town Willemstad). In case of a later start of the incubation, the samples were stored in white containers in the shade.

In all incubations raw seawater was used and, in some incubations, seawater filtered through $0.8 \mu \mathrm{m}$ filters (Millipore, polycarbonate ATTP), which removes about $80 \%$ of the phytoplankton of the sample, was used. The incubations were performed in plastic bags (polypropylene bags (Sarstedt special disposal bags] and Whirlpack bags) which had high transmission in the UVBR and UVAR range (Fig. 1). For the 3 $h$ incubations polyethylene bags (Whirlpack) were 


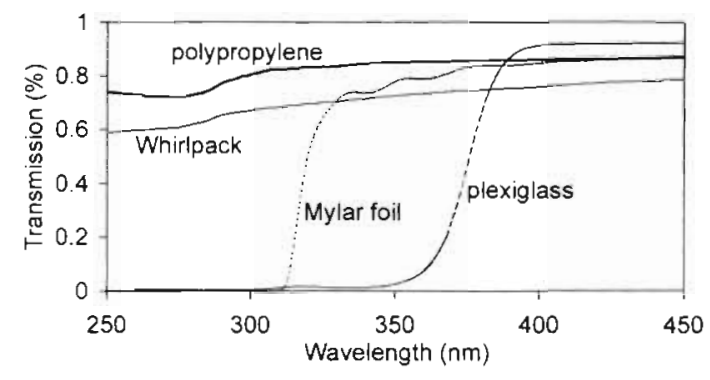

Fig. 1. Transmission spectra of different materials used in the experiments: plastic bags (polypropylene and Whirlpack) for incubating samples, Mylar foil (to shield off UVBR) and plexiglass (to shield off UVBR and UVAR $<375 \mathrm{~nm}$ )

used, filled with $800 \mathrm{ml}$ sample. For the longer incubations polypropylene bags were used, filled with about 3 to $8 \mathrm{l}$. For the determinations on carbohydrate contents $10 \mathrm{l}$ were incubated. All bags were placed just below the water surface in open trays (to provide cooling of the bags) close to the Carmabi pier. One tray was uncovered to allow maximal exposure to full sunlight. Another tray was covered with Mylar foil, shielding off radiation $<320 \mathrm{~nm}$, and yet another tray was covered with plexiglass, to shield off radiation $<375$ nm (Fig. 1). The dark control bags were packed in black bags. The transmission spectra of the plastic bags, Mylar foil and plexiglass (Fig. 1) were measured on a spectrophotometer (CARY model 3E UV-Visible [Double Beam]). The same sheet of Mylar foil was used for not more than $12 \mathrm{~h}$ of incubation in the sunlight, since long-term exposure to UVR can change the transmission spectrum considerably (Middleton \& Teramura 1993).

The $3 \mathrm{~h}$ incubations were started at 10:30 h. At the end of the incubation, samples $( \pm 100 \mathrm{ml})$ were taken from the bags with a syringe for determination of the leucine incorporation rate and bacterial counts; the remaining content was filtered through $10,0.8$ and $0.2 \mu \mathrm{m}$ polycarbonate filters (Poretics) for the quantification of DNA damage (thymine dimers). From countings it appeared that no phytoplankton passed through these $0.8 \mu \mathrm{m}$ filters (in contrast to the Millipore ATTP $0.8 \mu \mathrm{m}$ filters, where $20 \%$ of the phytoplankton still passed through the filters as earlier mentioned) and about $40 \%$ of the total bacteria in the sample remained on the filters. The experiments were performed between January 21 and April 3, 1997.

To determine the diurnal response to UVR, changes in leucine and thymidine incorporation and DNA damage and carbohydrate concentration were followed during the light period. Samples were taken in the morning as described earlier and incubated in polyethylene bags. Samples were taken (removal of 1 bag per sampling time) at regular time intervals (see times in the Figs. 5 \& 7). Experiments in which the diurnal changes in leucine and thymidine incorporation and DNA damage were followed were performed on March 11, 20 and April 3, 1997 and on January 29 and February 24, 1998. Experiments in which the diurnal changes in intracellular carbohydrates in the phytoplankton were followed were performed on March 10 , 11 and April 27, 1998.

Light measurements. Light measurements were performed during the incubations every $20 \mathrm{~s}$ using a Biospherical Instruments Model PUV 510 radiometer which measures UVR at 305, 320, 340 and $380 \mathrm{~nm}$ as well as PAR. At the measured wavelengths, the integrated radiation dose over the duration of the experiment was calculated.

For estimation of the biologically effective UVR, biodosimeters were exposed during all experiments to the same light conditions as the bags over the entire day. Every time bags were sampled, 2 dosimeters were removed and stored in the freezer. The used biodosimeters (calf thymus DNA in quartz tubes) were identical to the ones used by Boelen et al. (1999). After incubation, the biodosimeters were stored at $-20^{\circ} \mathrm{C}$ until analysis (quantification of thymine dimers in the home laboratory).

Leucine and thymidine incorporation. Leucine and thymidine incorporation rate was determined as described by Simon \& Azam (1989) using cold extraction. Leucine (final concentration $40 \mathrm{nM} ; 7.5$ to $10 \%$ leucine $\left[3,4,5-{ }^{3} \mathrm{H}\right]$-leucine (NEN), specific activity $180 \mathrm{Ci} \mathrm{mmol}^{-1}$ [Dupont de Nemours]) or thymidine (final concentration $10 \mathrm{nM}$ \{methyl- ${ }^{3} \mathrm{H}$-thymidine (NEN), specific activity 84 to $90 \mathrm{mCi} \mathrm{mmol}^{-1}$ [Dupont de Nemours]) was added to 3 subsamples of $10 \mathrm{ml}$ and to a formalin-fixed control. The subsamples were incubated in the dark for $60 \mathrm{~min}$ in an open tray in the water. The incubation was terminated by adding buffered formaldehyde $11 \%$ final concentration, $\mathrm{pH}$ 7.6). After extraction of the subsamples (30 min on ice after addition of $5 \%$ TCA final concentration), samples were filtered onto $0.2 \mu \mathrm{m}$ filters and thereafter rinsed 4 times with $2 \mathrm{ml} 5 \%$ TCA and twice with $2 \mathrm{ml}$ $0.2 \mu \mathrm{m}$ filtered seawater with formalin (2\%). The incorporated ${ }^{3} \mathrm{H}$-leucine and ${ }^{3} \mathrm{H}$-thymidine were determined by liquid scintillation counting (Racka Beta scintillation counter).

Carbohydrates. For quantification of the carbohydrate concentration about 31 of incubated seawater was filtered in triplicate over precombusted $\mathrm{GF} / \mathrm{F}$ filters. The filters were stored at $-20^{\circ} \mathrm{C}$ until analysis.

The estimation of the glucose concentration of the organisms collected on GF/F filters followed the GODPerid method of Boehringer (Werner et al. 1970), after hydrolysis of the samples (incubation in $2 \mathrm{~N} \mathrm{HCl}$ at $100^{\circ} \mathrm{C}$ for $1 \mathrm{~h}$ ), with glucose as standard. 
Bacterial counts. Bacteria were enumerated according to the procedure described by Hobbie et al. (1977). Subsamples of $5 \mathrm{ml}$ were stained with acridine orange (final concentration $0.01 \%$ ) and filtered onto $0.2 \mu \mathrm{m}$ filters (black polycarbonate). The filters embedded in immersion oil were stored on slides at $-20^{\circ} \mathrm{C}$ before enumerating. The number of bacteria was determined using an epifluorescence microscope.

DNA damage. At the end of the incubations, the samples were pressure-filtered through a series of 10 , 0.8 and $0.2 \mu \mathrm{m}$ filters (polycarbonate filters Poretics). After $30 \mathrm{~min}$ the filtration was stopped (about 1.5 to $2.0 \mathrm{l}$ was filtered) and the filters were frozen in liquid nitrogen and stored at $-20^{\circ} \mathrm{C}$ until analysis.

For the quantification of DNA damage, DNA collected on the filters was extracted from the filters. To the filters $750 \mu \mathrm{C}$ CTAB buffer $\left(2 \%\right.$ CTAB, $1.4 \mathrm{M} \mathrm{NaCl}_{1}$ $20 \mathrm{mM}$ EDTA, $100 \mathrm{mM}$ Tris-HCl $\mathrm{pH} 8$ ) and $1.5 \mu \mathrm{l}$ $\beta$-mercaplo-ehanol were added and the sampies were heated at $60^{\circ} \mathrm{C}$ for $30 \mathrm{~min}$. Subsequently, $750 \mu \mathrm{l} \mathrm{CIA}$ (chloroform: isoamylalcohol 24:1) was added, vortexed and centrifuged $(20000 \times g)$ for $10 \mathrm{~min}$. After centrifugation, the water phase was transferred to a new tube and $2 / 3$ volume cold isopropanol was added. After $1 \mathrm{~h}$ at $4^{\circ} \mathrm{C}$, the samples were centrifuged at this temperature for $30 \mathrm{~min}$. The pellets were resolved in ice-cold ethanol $(80 \%)$. After at least $15 \mathrm{~min}$ at $-20^{\circ} \mathrm{C}$, the samples were centrifuged for $30 \mathrm{~min}$ at $4{ }^{\circ} \mathrm{C}$. The pellets were dried and resolved in TE-buffer $(10 \mathrm{mM}$ TRIS pH 8, 1 mM EDTA) and treated with RNAse to remove RNA. The DNA concentration was determined in a fluorometer (Wallac 1420 Victor plate reader or Hitachi F2000 Fluorescence Spectrophotometer) after labelling the DNA with a fluorescent probe (Picogreen, Molecular Probes).

The thymine dimers in the DNA extracted from the material collected on the filters and in the biodosimeters were quantified via an immuno-dot-blot method as described by Boelen et al. (1999).

Statistics. Statistical analyses were done with Systat 7.0. The General Linear Model was applied to the data and the level of significance was tested with Pairwise Comparison (Bonferroni).

\section{RESULTS}

\section{Short-term exposure around noon}

Leucine incorporation rates in the dark incubations were in the range of 20 to $300 \mathrm{pmol}$ leucine incorporated $\mathrm{l}^{-1} \mathrm{~h}^{-1}$. The results of the treatments are all expressed as percentage of the incorporation rates of the sample incubated in the dark to allow comparison of different experiments and different dates. The aver-

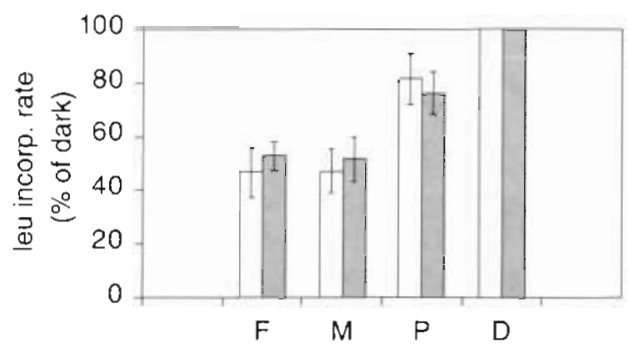

Fig. 2. Average leucine incorporation rates as percentage of the dark incubation in bags incubated under full solar radiation ( $F$ ), under Mylar foil (M, UVBR blocked light), under plexiglass ( $P$, blocking UVBR + UVAR $<375 \mathrm{~nm}$ ) and in the dark (D) after $3 \mathrm{~h}$ incubations around noon. Error bars represent the standard error of the mean. White bars: unfiltered seawater $(n=10)$, grey bars: $0.8 \mu \mathrm{m}$ filtered seawater $(n=6)$

ages of the leucine incorporation rates after $3 \mathrm{~h}$ incubations around noon of boin unfíitered and $0.8 \mu \mathrm{m}$ filtered samples are plotted in Fig. 2. A significant difference was found between incubation under full solar radiation and shielding off UVR $<375 \mathrm{~nm}$ (plexiglass; filtered sample: $p<0.05$, unfiltered: $p<0.0001$ ) and between shielding off UVBR (mylar foil) and shielding UVR<375 nm (plexiglass, filtered sample: $p<0.05$, unfiltered: $p<0.0001)$. No significant difference was found between incubations in full solar radiation and shielding off UVBR. No significant difference was found between the filtered and unfiltered samples. No changes in the number of bacteria in the different bags at the end of the incubation were found (Table 1).

In Fig. 3, the average DNA damage in the $<0.8 \mu \mathrm{m}$ fraction and biodosimeters incubated around noon for $3 \mathrm{~h}$ under different light conditions are shown. Consid-

Table 1. Number of bacteria $\left(\mathrm{N} \times 10^{5} \mathrm{ml}^{-1}\right)$ in unfiltered samples after incubation under full solar radiation $(F)$, under Mylar-foil ( $M$, shielding off UVBR), under plexiglass ( $\mathrm{P}$, shielding off UVBR and UVAR<375 nm) and in the dark (D). Standard error of the countings was on average $4 \%$ of the number (min. 3 and $\max .7 \%$ )

\begin{tabular}{|cccccc|}
\hline Date & $\begin{array}{c}\text { Hours of } \\
\text { incubation }\end{array}$ & $F$ & $\mathrm{M}$ & $\mathrm{P}$ & $\mathrm{D}$ \\
\hline 14 Feb 97 & 6.15 & 3.85 & & & 4.47 \\
18 Feb 97 & 3.00 & 3.84 & 4.02 & 4.02 & 4.01 \\
$4 \operatorname{Mar} 97$ & 3.00 & 3.52 & 4.13 & 4.10 & 4.47 \\
6 Mar 97 & 3.00 & 5.36 & 5.73 & 5.11 & 5.07 \\
11 Mar 97 & 7.20 & 4.54 & & & 3.63 \\
$19 \operatorname{Mar} 97$ & 3.00 & 4.08 & 3.56 & 3.39 & 3.45 \\
20 Mar 97 & 7.15 & 3.61 & 3.44 & 3.70 & 3.33 \\
26 Mar 97 & 3.00 & 3.46 & 3.29 & 3.14 & 3.54 \\
27 Mar 97 & 3.00 & 2.51 & 3.03 & 3.24 & 3.49 \\
3 Apr 97 & 7.20 & 3.39 & 3.44 & 3.56 & 3.83 \\
29 Jan98 & 7.35 & 3.18 & 3.79 & 3.06 & 3.83 \\
24 Jan 98 & 7.30 & 3.45 & 3.08 & 2.92 & 3.26 \\
\hline
\end{tabular}




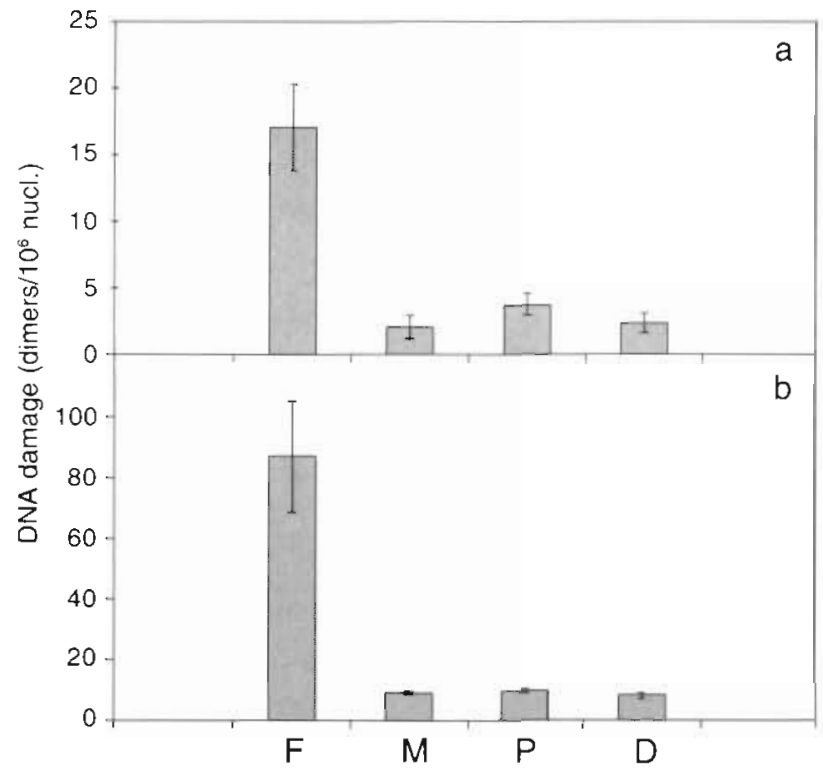

Fig. 3. Average DNA damage (thymine dimers per $10^{6}$ nucleotides) in (a) $<0.8 \mu \mathrm{m}$ fraction of seawater samples incubated in bags ( $n=3$ to 5 ) and (b) biodosimeters ( $n=5$ to 6$)$, under full solar radiation ( $F)$, under mylar foil ( $M$, UVB blocked light), under plexiglass ( $P$, blocking UVBR + UVAR $<375 \mathrm{~nm}$ ) and in the dark (D) after $3 \mathrm{~h}$ incubation around noon. Error bars represent the standard error of the mean.

erable DNA damage was only found in the incubations exposed to full solar radiation. The average DNA damage in this incubation differed significantly from the other incubations: shielding UVBR ( $p<0.0001)$, shielding UVR $<375 \mathrm{~nm}(\mathrm{p}<0.001)$ and in the dark $(p<0.0001)$. These differences were also found in the biodosimeters (with $\mathrm{p}<0.0001$ for all treatments). No differences among the shielding/dark treatments were found.

\section{Diurnal incubations}

In Fig. 4, representative diurnal courses of radiation of UVB-305 nm and integrated radiation of UVB and UVA are shown. During the day, the leucine and thymidine incorporation rate as percentage of the dark decreased in full solar radiation to about $30 \%$ (Fig. 5). The diurnal changes in the averages of leucine and thymidine incorporation rates as percentages of the dark of 4 and $2 \mathrm{~d}$, respectively, are shown for the 3 treatments. The leucine incorporation rate in the morning hours was also inhibited in the incubations with UVBR shielded off, but in the afternoon the rates increased in these incubations. In the incubations without UVR $<375 \mathrm{~nm}$ this increase was more pronounced, even up to a higher rate compared to the dark incubation, than when only UVBR was shielded off. The stimulation of the leucine incorporation rate in

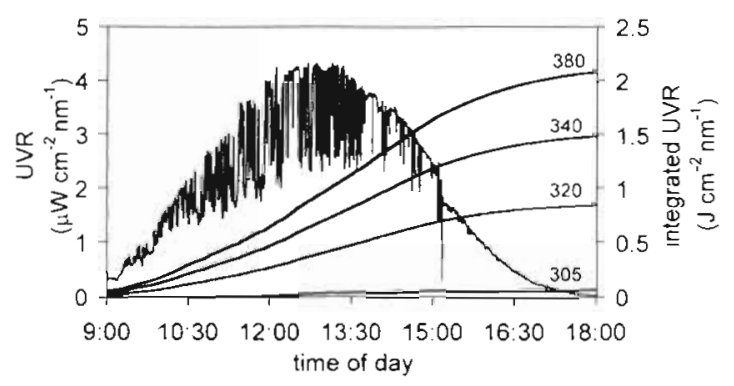

Fig. 4. A representative diurnal course of UVB radiation (305 $\mathrm{nm}$, scattered line) in $\mu \mathrm{W} \mathrm{cm}^{-2} \mathrm{~nm}^{-1}$, left $y$-axis, and the integrated UV radiation at $305,320,340$ and $380 \mathrm{~nm}$ in $\mathrm{J} \mathrm{cm}^{-2} \mathrm{~nm}^{-1}$, right $y$-axis

the incubations was found on 2 of the $4 \mathrm{~d}$ on which the diurnal changes of the leucine incorporation were followed. The thymidine incorporation was not determined on these days. On the other 2 days, the leucine incorporation showed a similar pattern as the thymidine incorporation. Inhibition of thymidine incorporation was also found in all treatments, but to a lower extent compared with full solar radiation when UVBR was shielded off and with the lowest inhibition when also short wavelength UVAR was shielded off.

This pattern is also clearly shown in the insets in Fig. 5, where the averages of all experiments and

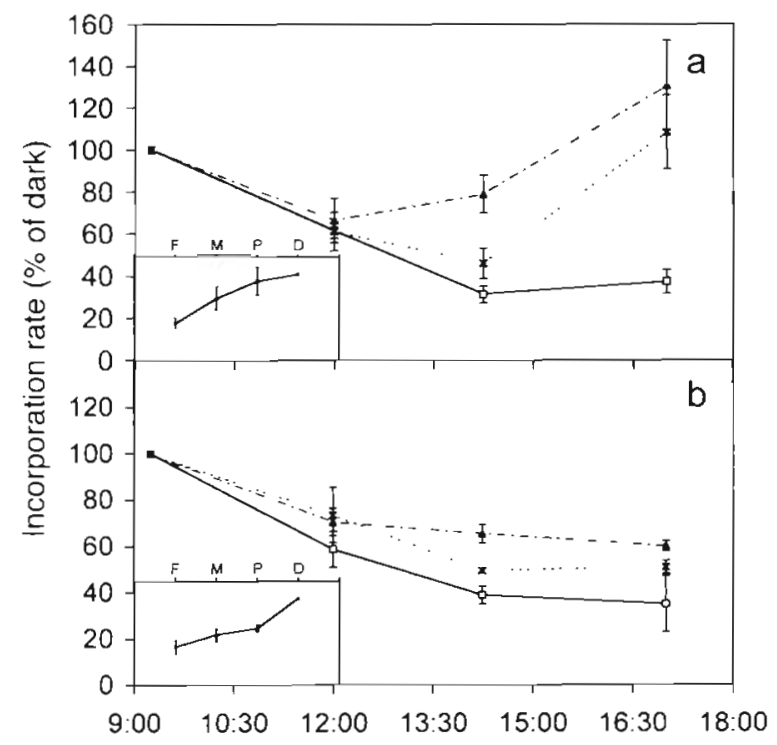

Fig. 5. Average diurnal courses of the incorporation rate (as \% of the dark control) of (a) leucine (average of 4 d) and (b) thymidine (average of $2 \mathrm{~d}$ ) of bacterioplankton in seawater incubated in bags under full solar radiation (ㅁ), under mylar foil ( $\mathbf{x}$ ) and under plexiglass ( $\mathbf{\Delta}$ ). Insets represent the averages of all days and all sampling times of (a) leucine incorporation rate $(n=12)$ and (b) thymidine incorporation rate $(n=6)$ under the 4 treatments as described in Fig. 2. Error bars represent the standard error of the mean 
Table 2. Contribution of different parts of the sun light spectrum to inhibition of leucine and thymidine incorporation as percentage of the total inhibition. The values are averages of 4 (leucine) and 2 (thymidine) $\mathrm{d}$

\begin{tabular}{lcccccc|}
\hline $\begin{array}{l}\text { Incubation } \\
\text { time }\end{array}$ & UVB & $\begin{array}{c}\text { Leucine } \\
\text { UVA PAR +UVA } \\
<375 \mathrm{~nm}>375 \mathrm{~nm}\end{array}$ & UVB & $\begin{array}{c}\text { Thymidine } \\
\text { UVA } \\
<375 \mathrm{~nm}>375 \mathrm{~nm}\end{array}$ \\
\hline $09: 15-12: 00 \mathrm{~h}$ & 0 & 13 & 87 & 27 & 0 & 73 \\
$09: 15-14: 15 \mathrm{~h}$ & 22 & 48 & 30 & 16 & 26 & 66 \\
\hline
\end{tabular}

relations with other wavelengths showed a lower $\mathrm{R}^{2}$

A lower inhibition after exposure to radiation without UVBR than exposure to full solar radiation was also found for the carbohydrate synthesis as shown in Fig. 7. The inset, in which the averages of the carbohydrate content of all experiments and sampling times are plotted, shows that the carbohydrate content under full solar radiation was a little higher than in

sampling times are plotted. For these averages of both leucine and thymidine incorporation a trend was found, with the lowest percentage of the dark incubation under full solar radiation a little higher when UVBR was shielded off and the highest when UVR $<375 \mathrm{~nm}$ was shielded off. Only the difference in average leucine incorporation between incubations under full solar radiation and with shieiding off UVR $<375 \mathrm{~nm}$ was significant $(\mathrm{p}<0.05)$. No significant differences were found in average thymidine incorporation between the different treatments. Inhibition in the morning appeared to be mainly caused by PAR for both leucine and thymidine incorporation (Table 2), while the contribution of inhibition by UVR was more pronounced in the early afternoon (but PAR still had the highest contribution to the inhibition of thymidine incorporation). The numbers of bacteria in the samples incubated during a day in the light and in the dark were comparable at the end of the incubation (Table 1).

All determined leucine incorporation rates as percentage of the dark rate when incubated in full solar radiation are summarized and plotted against the received UVBR dose ( $305 \mathrm{~nm}$ ) during the incubations in Fig. 6. The incorporation rates after $3 \mathrm{~h}$ incubation are included as well as the rates after various times of incubations during the day. A significant linear correlation was found for leucine incorporation rates as expressed in percentage of the dark control, while cor-

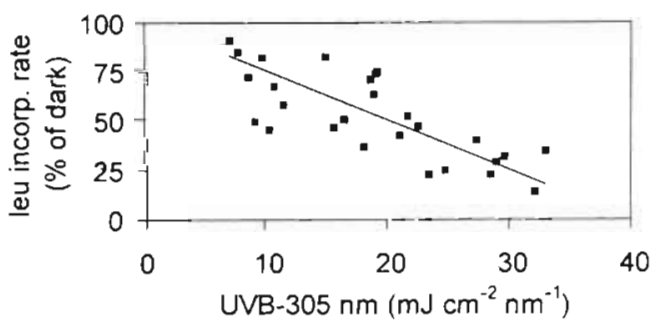

Fig. 6. Leucine incorporation rates of seawater as percentage of the dark incubation during various experiments plotted against the accumulated UVB radiation at $305 \mathrm{~nm}$ during the incubation periods. The line shows the fits of linear regression (intercept set at 100): $y=-2.51 x+100\left(R^{2}=0.55, n=27, p<0.01\right.$ ) the dark (where no carbohydrate synthesis can occur) and was the highest when UVR $<375 \mathrm{~nm}$ was shielded off. Only the difference in carbohydrate content between the dark incubation and incubation under mylar

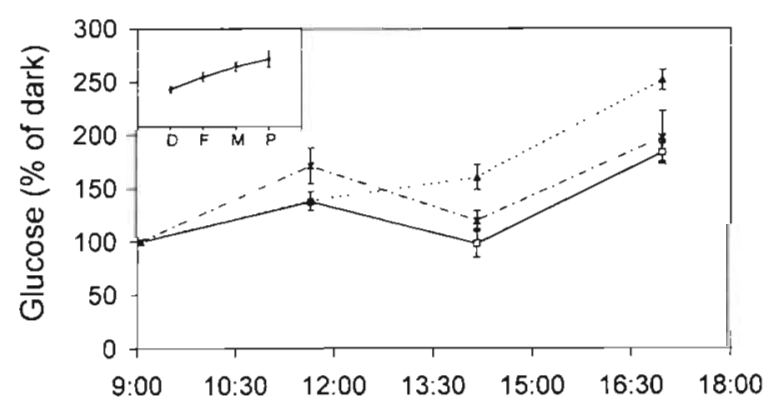

Fig. 7. Average diurnal changes in intracellular carbohydrate content of phytoplankton as percentage of the dark control $(\mathrm{n}=3)$, measured as glucose after hydrolysis of the polysaccharides, in seawater incubated in bags under full solar radiation (0), under Mylar foil (x) and under plexiglass ( $\boldsymbol{\wedge}$ ). Inset represents the averages of all days and all sampling times under the 4 treatments as described in Fig. 2

foil ( $p<0.05)$ and under plexiglass $(p<0.001)$ were significantly different. Only in the treatments without UVBR did the carbohydrate content increase notably during the day. In all light treatments an increase in the carbohydrate content was found in the morning and late afternoon, while in the incubation around noon a decrease was found.

The DNA damage in bacterioplankton $(<0,8 \mu \mathrm{m}$ fraction) increased from the morning to early afternoon (Fig. 8) and remained high until late afternoon. The DNA damage in the biodosimeters increased more or less continuously throughout the day. A significant correlation between DNA damage and the received UVBR (305 nm) dose could be found in the biodosimeters $\left(R^{2}=0.79, n=12, p<0.01\right)$, but not in the bacterioplankton fraction of the incubated seawater $\left(\mathrm{R}^{2}=\right.$ $0.36, n=9, p>0.5)$. The amount of thymine dimers in the $>0.8 \mu \mathrm{m}$ fraction was only $32 \% \pm 5(\mathrm{SE}, \mathrm{n}=17)$ of the amount of thymine dimers in the $<0.8 \mu \mathrm{m}$ fraction. 


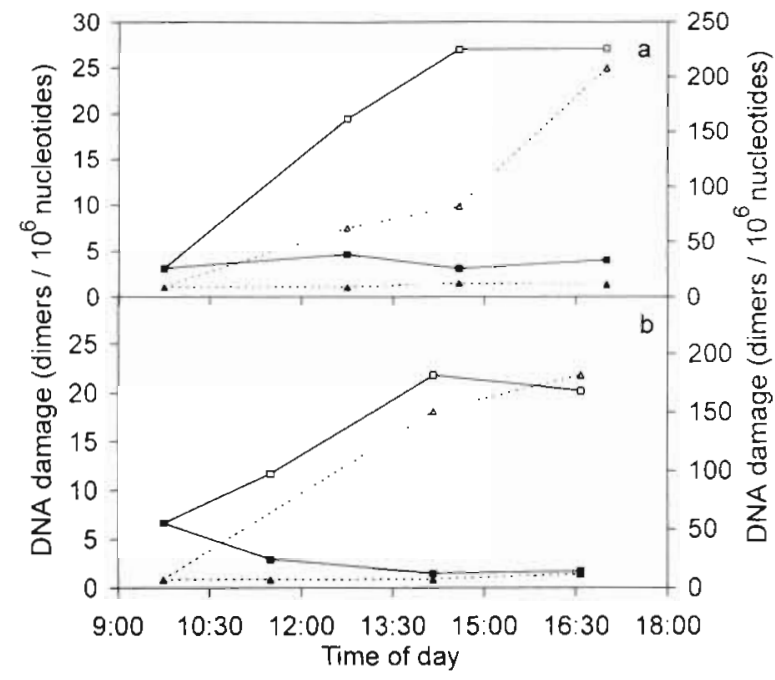

Fig. 8. Diurnal courses in DNA damage (thymine dimers per $10^{6}$ nucleotides) in the $<0.8 \mu \mathrm{m}$ fraction of seawater incubated in bags (o: under full solar radiation, $\mathbf{m}$ : in the dark; left-hand $y$ axis) and in biodosimeters ( $\triangle$ : under full solar radiation, $\mathbf{\Lambda}$ : in the dark, right $y$-axis) on (a) March 11, and (b) April 3, 1997

\section{DISCUSSION}

This study shows that sunlight has a large inhibiting effect on bacterioplankton and this inhibition should be taken into account when the microbial food web in tropical waters is considered. A trend was found for the inhibition of leucine and thymidine incorporation in bacterioplankton partly by UVBR, but to a higher extent by short wavelength UVAR and by long wavelength UVAR + PAR. UVBR only was responsible for DNA damage (thymine dimers) in bacterioplankton in the Caribbean Sea. Carbohydrate synthesis of phytoplankton appeared to be inhibited by both UVBR and by UVAR (<375 nm).

DNA damage in bacterioplankton ( $<0.8 \mu \mathrm{m}$ fraction) in both seawater samples and pure DNA (biodosimeters) was found only when incubated in bags under full solar radiation, indicating that thymine dimer formation was caused by UVB radiation. The highest DNA damage in the bacterioplankton was found in the early afternoon and remained constant until late afternoon. This pattern was also found in the inhibition of the leucine and thymidine incorporation, suggesting that the highest induction of thymine dimers and inhibition of the production occurred during the morning and early afternoon hours under full solar radiation, reaching a maximum in the early afternoon. The damage in the biodosimeters was still increasing in the afternoon. Since repair mechanisms are available in bacteria but not in pure DNA, this might explain this discrepancy. Due to a lower UVB intensity in the afternoon, pho- toenzymatic repair influenced by UVAR and PAR (Mitchell \& Karentz 1993, Kaiser \& Herndl 1997) could probably compensate for induced UVBR damage.

The amount of thymine dimers in the $>0.8 \mu \mathrm{m}$ fraction was only one-third of the dimers in the $<0.8 \mu \mathrm{m}$ fraction, suggesting that phytoplankton was less sensitive to UV induction of DNA damage. From countings it appeared that about 30 - to $40 \%$ of the total bacteria in the sample did not pass the $0.8 \mu \mathrm{m}$ filters. When this is taken into account, the DNA damage of the phytoplankton would have been even lower than one-third of the DNA damage in bacterioplankton. Jeffrey et al. (1996b) found a damage accumulation in the $>0.8 \mu \mathrm{m}$ fraction of about half the damage in the $<0.8 \mu \mathrm{m}$ fraction. Jeffrey et al. (1996b) explained the difference between the 2 fractions by the small size of the bacterioplankton: this precludes effective cellular shading or protective pigmentation (Garcia-Pichel 1994).

A significant correlation between DNA damage and the received UVBR (305 $\mathrm{nm}$ ) dose could be found in the biodosimeters, but not in the bacterioplankton fraction of the incubated seawater. One explanation for this discrepancy between biodosimeters and bacterioplankton might be that the amount of dimers in bacterioplankton did not increase anymore in the afternoon, while the amount of dimers in the biodosimeters was still increasing. As stated above, repair mechanisms might explain this. However, this does not settle it completely, since the correlation is still not significant if the values at the end of the day are removed $\left(\mathrm{R}^{2}=\right.$ $0.45, n=8, p>0.5)$. No correlation was found between DNA damage in the bacterioplankton fraction and inhibition of leucine incorporation rate. It can be questioned whether a correlation between protein synthesis and DNA damage can be expected. Dimers block the action of DNA polymerase, thereby preventing genome replication, and will thus have an effect on the growth rate. Protein synthesis might not be necessarily affected by this when no pro-novo synthesis of enzymes is needed for protein synthesis. From our results it appeared that thymine dimers were only induced by UVBR, while inhibition of leucine and thymidine incorporation was also found in incubations where UVBR was excluded. Thus, inhibition of protein synthesis (leucine incorporation), but also of DNA synthesis (thymidine incorporation), was certainly not only the consequence of induced thymine dimers. This might explain why no significant correlation was found between the inhibition of protein synthesis and the amount of thymine dimers. Inhibition of protein and DNA synthesis can also be caused by other factors like damage to enzymes or other cell compartments. The activity of bacterial ectoenzymes, for example, is found to be retarded under the influence of UVR (Herndl et al. 1993, Müller-Niklas et al. 1995). 
In the bacterial production, a trend was found, with the highest inhibition under full solar radiation, lower inhibition when UVBR was shielded off and the lowest inhibition when short wavelength UVAR was also shielded off. Only in the experiments in which the samples were incubated for $3 \mathrm{~h}$ around noon, shielding off UVBR did not result in an increase in the leucine incorporation. It is probable that, due to the very high irradiance at that time, the effects of UVAR and PAR were already very high and overshadowed the effects of UVBR. Also, the use of Whirlpack bags with lower transmittance to UVBR in the $3 \mathrm{~h}$ experiments, compared to polypropylene bags as used in the diurnal experiments, might have contributed to this. Many studies report an inhibitory effect of UVBR on the leucine and thymidine incorporation rates (Bailey et al. 1983, Herndl et al. 1993, Aas et al. 1996, Jeffrey et al. 1996a), but inhibition by UVAR and PAR has also been found in other studies. Sieracki \& Sieburth (1986) showed that UVAR was responsible for the observed growth delay of marine bacteria. Sommaruga et al. (1997) found that both UVAR and PAR contributed to the inhibition of thymidine and leucine incorporation in bacterioplankton. Inhibition by PAR was also observed by Aas et al. (1996), Bailey et al. (1983) and Garabétian (1991), and Gourmelon et al. (1994) found that visible light caused a drastic decrease of culturable bacteria. They suggested that reactive oxygen species might be involved in this process, since the effect of light was much lower in anaerobic conditions while scavengers reduced the effect a little. The contribution of PAR to the total inhibition was much higher in our study (Table 2) than in the study of Aas et al. (1996), who found a contribution of PAR of only $23 \%$ of total inhibition of leucine incorporation and even a stimulation of thymidine incorporation compared to the dark incubation.

Although inhibition of the leucine incorporation rate was not solely caused by UVBR, a significant linear correlation was found between the leucine incorporation rate as percentage of the dark incubation (of both the short-term and the diurnal experiments) and the UVB photon dose (305 nm). Significant correlations were also found with other wavelengths and with the sum of the 4 measured wavelengths in the UVR region, but the best correlation (highest $R^{2}$ ) was found with UVBR (305 $\mathrm{nm}$ ). Since all parts of the sunlight spectrum contributed to the inhibition, UVBR-305 $\mathrm{nm}$ can be seen as a measure for the total light dose. It is remarkable that linear regression appeared to fit the data best since one would tentatively assume that an exponential decline in bacterial production with increasing dose would give a better fit as described by Herndl et al. (1993).
The absence of significant differences between filtered and unfiltered samples in response to UVR (Fig. 2) suggests that the effect of UVR on the photosynthetic and bacterivorous plankton affecting the leucine incorporation rate was too small to be detected in our experiments. From countings it appeared that the filtered sample still contained about $10 \%$ of picophytoplankton after filtration over $0.8 \mu \mathrm{m}$ filters, which would have deteriorated the difference between the filtered and the unfiltered samples to a limited extent. It is known that the primary producers in tropical waters are dominated by coccoid cyanobacteria and prochlorophytes smaller than $1 \mu \mathrm{m}$ in diameter (Ducklow 1990). From other studies it also appeared that grazers can pass through filters with this small pore size (Fuhrman \& McManus 1984, Cynar et al. 1985). However, we assume that the concentration of the bacterivores will have been greatly reduced since the leucine incorporation rate in the dark bags with filtered water increased much more than in the bags with unfiltered water (data not shown).

The results of the diurnal incubations (Fig. 5) show that in the morning hours (until noon) inhibition of the leucine incorporation rate was found for all light treatments, suggesting that PAR + long wavelength UVAR was mainly the cause of this inhibition as also appears in Table 2. In the afternoon, the incorporation rate in the samples incubated under full solar radiation decreased further, while the rate in the samples incubated without UVBR became even higher compared to the dark incubation. The bacterial numbers were comparable in the bags at the end of the incubation, which suggests that the protein synthesis per cell differed between the samples. The observed stimulation in the afternoon when incubated without UVBR was partly due to a decrease in the incorporation rate in the dark incubations, but this cannot explain the large difference between rates in the incubations with and without UVBR. This difference might be explained by bacterial utilization of an increased extracellular release by phytoplankton (Gomes et al. 1991, Obernosterer \& Herndl 1995) due to photosynthesis in the incubations without UVBR. If the amount of excretion of carbohydrates is closely coupled to the amount of intracellular carbohydrates, this explanation is consistent with our results on intracellular carbohydrate synthesis by phytoplankton, which occurred only in the incubations without UVBR. Another explanation could be that the leucine incorporation was stimulated by the products from photolysis of DOM induced by UVAR + PAR more than it was inhibited by this radiation. The products of photolysis of DOM are predominantly low molecular carbon compounds which might be taken up rapidly by bacterioplankton (Wetzel et al. 1995). Also, about two-thirds of the photolytic activity is caused by 
UVAR + PAR and only one-third by UVBR (Herndl 1997). Another possible explanation might be the repair of damage which was still present from the previous day or induced in the morning. Recovery of protein synthesis under exposure to UVAR and PAR was also found by Kaiser \& Herndl (1997).

It can be questioned whether a dark incubation is a good control for incubations under different light conditions, since the extracellular release of phytoplankton will be different in the dark than in the light, which may cause changes in the bacterial activity. Aas et al. (1996) observed an enhanced incorporation of leucine compared to the dark control, which they explained by a stimulation of bacterial activity by photosynthesis in the light. In our study, a decrease in the leucine incorporation rate in the PAR incubation was observed, indicating that the damaging effects of long wavelength UVAR and PAR prevailed over the potentially stimulatory effects of photosynthesis or photolysis of DOM.

Synthesis of intracellular carbohydrates by phytoplankton appeared to be inhibited under full solar radiation, to the extent that no significant difference could be found between incubations in the dark and those under full solar radiation. The phytoplankton cells incubated without UVBR had significantly higher carbohydrate contents than those incubated in the dark, suggesting that primary production could only occur when UVBR was shielded off during incubations at the surface. The inhibitory effect of UVR on the synthesis of carbohydrates, also measured as glucose molecules after hydrolysis, was also found by Goes et al. (1996). The carbohydrate content in the incubations with UVR $<375 \mathrm{~nm}$ shielded off was higher, although not significantly, than in the incubations with UVBR shielded off. Helbling et al. (1992) showed that UVAR was responsible for over $50 \%$ of the total inhibition of photosynthesis of phytoplankton and with less than $50 \%$ due to UVBR. The amount of thymine dimers appeared to be rather low in comparison to bacterioplankton, but could have contributed to the inhibition of carbohydrate synthesis in phytoplankton. In the diatom Cyclotella sp., growth rate reduction appeared to be strongly related to thymine dimer content (Buma et al. 1997). However, inhibition can also be the result of inactivation of photosystems or destruction of pigments, proteins or membranes (Vincent \& Roy 1993. Karentz et al. 1994). An increase in carbohydrate content in the incubations without UVBR was only found in the morning hours (until midday) and in late afternoon (after 14:00 h), suggesting that photo-inhibition by high PAR irradiance occurred around midday. Photo-inhibition by high photon irradiance of PAR, resulting in a decrease in photosynthesis, is an often observed phenomenon in phytoplankton (Vincent et al. 1984, Henley 1993).
This study clearly showed the potential inhibition of UVR and PAR on protein and DNA synthesis in bacteria, which certainly affects the microbial food web in the water column. We investigated the most extreme situation of light exposure: incubation at the surface during the entire day. Depth irradiance is decreasing, and therefore the inhibition and DNA photodamage will also decrease with depth. Jeffrey et al. (1996a,b) showed a depth profile of DNA damage with an exponential decrease with depth on a calm day. With mixing, no differences were found between different depths and time. However, this is not necessarily always the result of mixing. Neale et al. (1998) showed with a model that inhibition (of photosynthesis in Antarctic phytoplankton) can be either enhanced or decreased by vertical mixing, compared to static profiles, depending on the depth of the mixed layer.

Acknowledgements. The work of P.M.V. was financed by the Netherlands Foundation for the Advancement of Tropical Research (grant W 84-404). The Biospherical Instruments Model PUV radiometer was provided by an EU grant (MICOR, project number EV5V-CT94-0512). We thank G. J Herndl for the critical review of the manuscript and Jan Jaap Poos and Bonnie B. Scheper for assistance with the fieldwork in 1998

\section{LITERATURE CITED}

Aas P, Lyons MM, Pledger R, Mitchell DL, Jeffrey WH (1996) Inhibition of bacterial activities by solar radiation in nearshore waters and the Gulf of Mexico. Aquat Microb Ecol 11:229-238

Bailey CA, Neihof RA, Tabor PS (1983) Inhibitory effect of solar radiation on amino acid uptake in Chesapeake Bay bacteria. Appl Environ Microbiol 46:44-49

Baker KS, Smith RC, Green AES (1980) Middle ultraviolet radiation reaching the ocean surface. Photochem Photobiol 32:367-374

Boelen P, Obernosterer I, Vink AA Buma AGJ (1999) Attenuation of biologically effective UV radiation in tropical atlantic waters measured with a biochemical DNA dosimeter. Photochem Photobiol 69(1):34-40

Buma AGJ, Engelen AH, Gieskes WWC (1997) Wavelengthdependent induction of thymine dimers and growth rate reduction in the marine diatom Cyclotella sp. exposed to ultraviolet radiation. Mar Ecol Prog Ser 153:91-97

Buma AGJ, Van Hannen EJ, Raza L, Veldhuis MJW, Gieskes WWC (1995) Monitoring uitraviolet-B-induced DNA damage in individual diatom cells by immunofluorescent thymine dimer detection. J Phycol 31:314-321

Crutzen PJ (1992) Ultraviolet radiation on the increase. Nature 356:104-105

Cynar FJ, Estep KW, Sieburth JM (1985) The detection and characterization of bacteria-sized protists in 'protist-free' filtrates and their potential impact on experimental marine ecology. Microb Ecol 11:281-288

Ducklow HW (1990) The biomass, production and fate of bacteria in coral reefs. In: Dubinsky Z (eds) Ecosystems of the world: coral reefs. Elsevier, Amsterdam, p 265-289

Fuhrman JA, McManus GB (1984) Do bacteria-sized marine 
eukaryotes consume significant bacterial production? Science 224:1257-1260

Garabétian $\mathrm{F}$ (1991) ${ }^{14} \mathrm{C}$-glucose uptake and ${ }^{14} \mathrm{C}-\mathrm{CO}_{2}$ production in surface microlayer and surface-water samples: influence of UV and visible radiation. Mar Ecol Prog Ser $77: 21-26$

Garcia-Pichel F (1994) A model for the internal self-shading in planktonic organisms and its implications for the usefulness of ultraviolet sunscreens. Limnol Oceanogr 39: $1704-1717$

Goes JI, Handa N, Taguchi S, Hama T, Saito H (1996) Metabolism of neutral monosaccharide constituents of storage and structural carbohydrates in natural assemblages of marine phytoplankton exposed to ultraviolet radiation. Limnol Oceanogr 417:1478-1489

Gomes HdR, Pant A, Goes JI, Parulekar AH (1991) Heterotrophic utilization of extracellular products of phytoplankton in a tropical estuary. J Plankton Res 13:487-498

Gourmelon M. Cillard J, Pommepuy M (1994) Visible light damage to Escherichia coli in seawater: oxidative stress hypothesis. J Appl Bacteriol 77:105-112

Helbling EW, Villafañe V, Ferrario M, Holm-Hansen O (1992) Impact of natural uitraviolet radiation on rates of photosynthesis and on specific marine phytoplankton species. Mar Ecol Prog Ser 80:89-100

Henley WJ (1993) Measurement and interpretation of photosynthetic light-response curves in algae in the context of photoinhibition and diel change. J Phycol 29:729-739

Herndl GJ (1997) Role of ultraviolet radiation on bacterioplankton activity. In: Häder DP (ed) The effects of ozone depletion on aquatic ecosystems. RG Landes Company, Austin, TX, p 143-154

Herndl GJ, Müller-Niklas G, Frick J (1993) Major role of ultraviolet-B in controlling bacterioplankton growth in the surface layer of the ocean. Nature 361:717-719

Herndl GJ, Brugger A, Hager S, Kaiser E, Obernosterer I, Reitner B, Slezak S (1997) Role of ultraviolet-B radiation on bacterioplankton and the availability of dissolved organic matter. Plant Ecol 128:42-51

Hobbie JE, Daley RJ, Jasper S (1977) Use of Nuclepore filters for counting bacteria by epifluorescence microscopy. Appl Environ Microbiol 33:1225-1228

Holm-Hansen O, Lubin D, Helbling EW (1993) Ultraviolet radiation and its effects on organisms in aquatic environments. In: Young AR, Björn LO, Moan J, Nultsch W (eds) Environmental UV photobiology. Plenum Press, New York, p 379-425

Jeffrey $W H$, Aas $P$, Lyons MM, Coffin RB, Pledger RJ, Mitchell DL (1996a) Ambient solar radiation-induced photodamage in marine bacterioplankton. Photochem Photobiol 64:419-427

Jeffrey $W H$, Pledger RJ, Aas $P$, Hager $S$, Coffin RB, Von Haven R, Mitchell DL (1996b) Diel and depth profiles of DNA photodamage in bacterioplankton exposed to ambient solar ultraviolet radiation. Mar Ecol Prog Ser 137: 283-291

Kaiser E, Herndl GJ (1997) Rapid recovery of marine bacterioplankton activity after inhibition by UV radiation in coastal waters. Appl Environ Microbiol 63:4026-4031

Karentz D, Cleaver JE, Mitchell DL (1991) Cell survival characteristics and molecular responses of Antarctic phytoplankton to ultraviolet-B radiation. J Phycol 27:326-341

Karentz D, Bothwell ML, Coffin RB, Hanson A, Herndl GJ, Kilham SS, Lesser MP, Lindell M, Moeller RE, Morris DP, Neale PJ, Sanders RW, Weiler CS, Wetzel RG (1994)
Impact of UV-B radiation on pelagic freshwater ecosystems: report of working group on bacteria and phytoplankton. Arch Hydrobiol Beih Ergebn Limnol 43:31-69

Lindell MJ, Graneli W, Tranvik LJ (1995) Enhanced bacterial growth in response to photochemical transformation of dissolved organic matter. Limnol Oceanogr 40:195-199

Lyons MM, Aas P, Pakulski JD, Van Wasbergen L, Miller RV, Mitchell DL, Jeffrey WH (1998) DNA damage induced by ultraviolet radiation in coral-reef microbial communities. Mar Biol 130:537-543

Madronich S (1993) The atmosphere and UV-B radiation at ground level. In: Young, AR, Björn LO, Moan J, Nultsch W (eds) Environmental UV photobiology. Plenum Press, New York, p 1-39

Madronich S (1994) Increases in biologically damaging UV-B radiation due to stratospheric ozone reductions: a brief review. Arch Hydrobiol Beih Ergebn Limnol 43:17-30

Middleton EM, Teramura AH (1993) Potential errors in the use of cellulose diacetate and mylar filters in UV-B radiation studies. Photochem Photobiol 57:744-751

Mitchell DL, Karentz D (1993) The induction and repair of DNA photodamage in the environment. In: Young AR, Bjorn LO, Moan J, Nuitsch W (eds) Environmenial UV Photobiology. Plenum Press, New York, p 345-377

Müller-Niklas G, Heissenberger A, Puskaric S, Herndl GJ (1995). Ultraviolet-B radiation and bacterial metabolism in coastal waters. Aquat Microb Ecol 9:111-116

Neale PJ, Davis RF, Cullen JJ (1998) Interactive effects of ozone depletion and vertical mixing on photosynthesis of Antarctic phytoplankton. Nature 392: 585-589

Obernosterer I, Herndl GJ (1995) Phytoplankton extracellular release and bacterial growth: dependence on the inorganic N:P ratio. Mar Ecol Prog Ser 116:247-257

Regan JD, Carrier WL, Gucinski $H$, Ola BL, Yoshida $H_{\text {, }}$ Fujimura RK, Wicklund RI (1992) DNA as solar dosimeter in the ocean. Photochem Photobiol 56:35-42

Sieracki ME, Sieburth JM (1986) Sunlight-induced growth delay of planktonic marine bacteria in filtered seawater. Mar Ecol Prog Ser 33:19-27

Simon M. Azam F (1989) Protein content and protein synthesis rates of planktonic marine bacteria. Mar Ecol Prog Ser 51:201-213

Smith RC, Cullen JJ (1995) Effects of UV radiation on phytoplankton. Rev Geophys 33 (Suppl 2):257-262

Sommaruga R, Oberleiter A, Psenner R (1996) Effect of UV radiation on the bacterivory of a heterotrophic nanoflagellate. Appl Environ Microbiol 62:4395-4400

Sommaruga R, Obernosterer I, Herndl GJ, Psenner R (1997) Inhibitory effect of solar radiation on thymidine and leucine incorporation by freshwater and marine bacterioplankton. Appl Environ Microbiol 63:4178-4184

Vincent WF, Neale PJ, Richerson PJ (1984) Photoinhibition: algal responses to bright light during diel stratification and mixing in a tropical alpine lake. J Phycol 20:201-211

Vincent WF, Roy S (1993) Solar ultraviolet-B radiation and aquatic primary production: damage, protection, and recovery. Environ Rev 1:1-12

Werner W, Rey HG, Wielinger H (1970) Properties of a new chromogen for the determination of glucose in blood according to the GOD/POD method. Z Analyt Chem 252: $224-226$

Wetzel RG, Hatcher PG, Bianchi TS (1995) Natural photolysis by ultraviolet irradiance of recalcitrant dissolved organic matter to simple substrates for rapid bacterial metabolism. Limnol Oceanogr 40:1369-1380

Submitted: September 16, 1998; Accepted: June 2, 1999

Proofs received from author(s): October 29, 1999 